\title{
Complaints of Indonesian Migrant Workers in Hong Kong to Their Husband Behaviors
}

\author{
Netty Nurdiyani \\ Universitas Sebelas Maret \\ nettynurdiyani@ymail.com \\ Tri Wiratno \\ Universitas Sebelas Maret \\ tri_wiratno@staff.uns.ac.id
}

\author{
Djatmika \\ Universitas Sebelas Maret \\ djatmika@staff.uns.ac.id \\ Sumarlam \\ Universitas Sebelas Maret \\ sumarlam@staff.uns.ac.id
}

\author{
Riyadi Santosa \\ Universitas Sebelas Maret \\ riyadisantosa@staff.uns.ac.id
}

\begin{abstract}
Complaints are all utterances that are born out of misery. Therefore, the complaints of IMWs in HK are intended as utterances that show the sorrow of the IMWs. The aim of this research is to find out forms of complaints shown by the IMWs relating to the behavior of their husbands who are staying in Indonesia. This study examines the writings of IMWs published in Iqro and CahayaQu magazines in 2014. The data collected from the selected rubrics, namely La Tahzan and Curahan Hati, Analysis were made based on Appraisal theory The result showed that doubts, sadness, pain, and anger are outnumber than affection and trust to their husbands.
\end{abstract}

Keywords-complaint; migrant worker; behaviors; apparaisal; attitude

\section{INTRODUCTION}

Hong Kong (HK) is a special administrative region of the People Republic of China. Hong Kong is one of the seven favorite destinations for the Indonesian Migrant Workers (IMWs). Approximately 154 thousands IMWs work here, with nearly $2.5 \%$ of them are male. Most IMWs work as housekeepers.

Becoming migrant workers will certainly require quite a long period of time. This will probably cause family related problems, such as problems with parents, husbands, children or other relatives. The appearing problems will result in complaints among the IMWs.

Complaints are all utterances resulted from distress (KBBI, 2008, p. 660). The distress may be shown in the forms of sorrow, pain, or upset. Therefore, when the IMWs complain they at the same time exhibit sadness that the fill in their hearts.

Complaints are related to feelings or emotions. An evaluation to the feelings or emotions is contained in the appraisal review. In the review, the emotional expression to human, namely the affect system, is defined as psychological reaction to behavior, text or process, and phenomenon. In this research, the analysis of the affect system was performed to these rubrics: La Tahzan and
Surat Pembaca of the CahayaQu (CQ) magazine and Curahan Hati of Iqro magazines. Both magazines use the Indonesia language and are published in Hong Kong.

\section{LITERATURE REVIEW}

\section{A. Appraisal}

The Appraisal Theory was the development of Functional Systemic Linguistics created by Halliday $(1985 / 1994)$ and was related to interpersonal meaning and discourse semantic within social relation negotiation text by communicating emotion, evaluation, and appreciation. An appraisal device developed by Martin \& Rose (2007) was used to analyze the spirits of the writers. According to Martin \& Rose (2007, p. 27) the appraisal system referred to appraisal relating to the evaluation of attitudes negotiated within the text, the involved strength of emotion and feeling observable in the texts, and how values of things or objects resulted and adjusted to the readers. The appraisal system was closely related to the doers of the communication and the social relation between them (in this case the writers/contributors and readers). Appraisal was a frame of theoretical concept to evaluate a language. The appraisal system related to one metafunction of a language, namely the interpersonal system. The appraisal framework consisted of three subsystems, namely attitude, graduation, source of attitude.

\section{B. Attitude}

Within the appraisal system, attitude comprises the centre of evaluation. Attitude is categorized into three evaluation domains, namely affect (people's feelings), judgment (people's character), and appreciation (value of things). Affect deals with registering positive and negative feelings: people feel happy or sad, confident or anxious, interested or bored. Judgment is concerned with people's attitudes towards behavior, which people admire or criticize, 
praise or condemn. Appreciation deals with evaluations of natural phenomena, according to the ways in which they are valued not in a given field (Martin \& Rose, 2007). Affect and judgment, appreciation can be positive and negative.

Here is the appraisal system developed by Martin and Rose (2007).

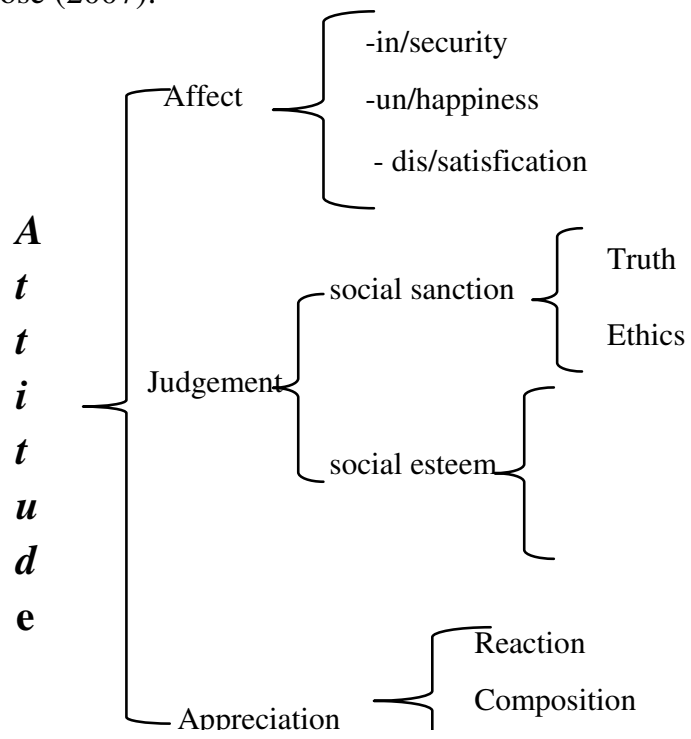

(Modified from Martin\& Rose, 2007)

Diagram 1.Attitude Concept

\section{METHOD}

Data of the research were collected from pieces of writing written by the IMWs which were found in the following rubrics:
1) La Tahzan of the CahayaQu (CQ) Magazine.
2) Curahan Hati of the Iqro (IQ) Magazine.

It should be noted that those pieces of writing were written by the IMWs and not by the editorial staff of the magazines. The selected pieces of writing were those written by the IMWs in 2004. Purposive technique was adopted to select the samples.

The selected data were those which represented the criteria specified by Sutopo, (2002, p. 56) and Santosa (2017, p. 33) namely texts which contain IMWs' complaints regarding to the behavior of their husbands. The results of this research will not be used to make a generalization of the specified population.

This research was a case study research so that the research would not be used to generalize the attitude of the IMWs against their husband's behaviors. After being collected, the data were analyzed using an interactive model of the qualitatively analyzed content. The analysis was conducted in four stages: domain analysis, taxonomy analysis, componential analysis, and cultural theme analysis (Spradely, 1997; Santosa, 2017, p. 66).

The domain analysis was used to select language units classified as data. The taxonomy analysis was used to see the appraisal category within the text. The componential analysis was used to see the exposure of the component and taxonomy domains and the relational pattern of both. The cultural theme analysis was aimed at finding relational pattern of situational and cultural contexts within the text. (Spradely, 1997; Santosa, 2017, p. 143).

\section{RESULT AND DISCUSSION}

\section{A. Types of Analyzed Text}

To evaluate text with appraisal system the genre of the text should first be specified to affect the discourse structure. As a system, a genre tries to map/pattern a culture. (Martin and Rose, 2008, p. 231). Genre is not a language, it is still within the cultural context (Martin, 1992; Santosa, 2010, p. 70) or still within the social context (Reinolds dalam Vestengaard, 2000; Santosa, 2010, p. 70).

Complaint texts are found in almost all rubrics' newspapers. Text structures in newspapers are usually known as macro genre. This genre is generated within the sub-culture known as discource community or professional institutions (Swales, 1990; Bhatia 1997 Santosa et all, 2014) in news, editorials, letters to editor, opinion, and others. These macro genres were developed from mixed micro genres, which represent genre complexing of recount, description, explanation, exposition, or/and discussion (Santosa et all, 2014; Santosa, 2011, p. 75).

The analyzed texts were written by the IMWs in HK and were contained in the rubrics of La Tahzan dan Curahan Hati. Both rubrics are categorized as letters to editors. However, when their readers used the rubrics to actualize themselves, they adopted two types of macro genres, namely narration and discussion.

Third genres are off two different sources. The narration and anecdot genres are based on stories of western communities, while the discussion genre is categorized as a factual genre. (Martin, 1992; Santosa, 2011, p. 76). Both genres are also distinguished on their text structure and linguistic characteristics used within the text.

Discussing a text cannot be separated from discussing the structure and texture of the text (Djatmika, 2015). Text structure comprises the character of the text in the form of text structure containing certain discourse units. The structure will require grammatical characters and choice of words conforming the intended goals. The texture of text will consist of cohesion system, lexicogrammar, and graphology or phonology. (Djatmika, 2015; Santosa, 2011). The cohesion of such structure and texture is called register. (Santosa, 2011; Santosa et al, 2014).

Appraisal is a text evaluation system through analysis apparatus such as attitude, engagement, and graduation. The research focused on attitude domain which consisted of affect, judgment, and appreciation. To understand those types of affect, a role of the lexicogrammar will be needed because it provides differences of the affect types.

Question and answer (discussion) text is a type of text accommodated by most newspapers and magazines. Magazines will provide special pages for this question and answer session. In IQ and CQ magazines, the session was placed in Letter to editor, Cahaya Fiqih, La Tahzan, and Curahan Hati rubrics. The structure of this question and 
answer text will usually consist of problem, argument, and questions. The texture of the text will express types of action, mental behavior and relational behavior.

These two question and answer texts there were 19 clauses, consisting of 8 affects, 9 judgments, and 2 appreciations, which all expressed the complaints by the IMWs HK. The affect, judgment, and appreciation can be positive or negative. bisa bersifat negatif maupun positif.

Affects within the texts were observable in the following clauses:

1) Suami saya akhir-akhir ini uring-uringan tentang sekolah saya (1/3) (My husband recently angry with my children school).

2) Tapi kalau suami nggak meridloi, saya juga bingung. (1/5a-5b) (But if my husband does not allow me, I am confused)

3) Gimana melupakan penghinatan suami? (2/2c-2d) (How to forget my husband's betrayal).

4) Saya begitu percaya padanya (2/3) ( I am truly trust him).

5) Tapi sulit sekali mempercayainya lagi (2/6) (But, it's hard to trust him again).

6) Di sisi lain, saya nggak ingin cerai karena ada anak (2/7) (On the other side, I don't want to divorce because we already have children)

The above mentioned clauses were written by the IMWs HK regarding to their husbands' behavior/ attitude. Clauses number (2) and (5) begin with conjunction Tapi (But). Nevertheless, they are both different. Clause (2) is multi voicing or heteroglos. This conjunction has no function. If it is deleted, it won't affect the meaning of the clause. The use of conjunction Tapi (But) in this clause comprises the application of concession. Meanwhile, The use of conjunction Tapi (But) in clause (5) is monoglos because the utterance derives from the IMWs themselves.

As a whole, the attitude within the question and answer text are described in this diagram.

TABLE I. ATTITUDE IN QUESTION ANSWER TEXT

\begin{tabular}{|l|c|c|c|c|c|c|c|}
\hline \multirow{3}{*}{ Text } & \multicolumn{5}{|c|}{ Attitude } & Number \\
\cline { 2 - 7 } & \multicolumn{2}{|c|}{ Affect } & \multicolumn{2}{|c|}{ Judg. } & \multicolumn{2}{c|}{ Apprc. } & \multirow{2}{*}{ Of } \\
\cline { 2 - 7 } & + & - & + & - & + & - & Clause \\
\hline 1 & 1 & 2 & - & 3 & - & 1 & 7 \\
\hline 2 & 1 & 4 & 3 & 3 & - & 1 & 12 \\
\hline & & & & & & & \\
\hline$\sum$ & 2 & 6 & 3 & 6 & - & 1 & 19 \\
\hline
\end{tabular}

Source of attitude in question answer text consist of monoglos (18) and heteroglos (1).

In anecdote text there were also complaints by the IMWs regarding to the husbands' behavior/attitude. The text consisted of 58 clauses as shown in this table.

TABLE II. ATTITUDE IN ANECDOTE TEXT

\begin{tabular}{|l|c|c|c|c|c|c|c|}
\hline \multirow{3}{*}{ Teks } & \multicolumn{5}{|c|}{ Attitude } & Number \\
\cline { 2 - 6 } & \multicolumn{2}{|c|}{ Affect } & \multicolumn{2}{|c|}{ Judg. } & \multicolumn{2}{c|}{ Apprc. } & \multirow{2}{*}{ Of } \\
\cline { 2 - 6 } & + & - & + & - & + & - & Clause \\
\hline 1 & 6 & 4 & 8 & 21 & 11 & 8 & 58 \\
\hline
\end{tabular}

Source of attitude in anecdote text consist of monoglos (52) dan heteroglos (6). The heteroglos were projection and concision.

Some clauses related to the complaints are as follow:

7) Lihat gubuk reyot saya tidak tega (3/13) (I cannot hold on to see my rickety hut).

8) Saya malu, (3/20a) (I was ashamed)

9) lalu minta pisah (3/20b) (The he ask for a divorce)

10) saya biarkan dia sendiri (3/20c) (I let him alone)

11) saya berusaha (3/24a) (I try)

12) untuk diam (3/24b) (To keep silent)

13) dan melupakan semua itu (3/24c) (and forget all of this).

The complaints were exp-ressed by the IMWs in thae following phrases: Ekspresi keluh kesah BMI HK dinyatakan dengan frasa tidak tega (cannot hold on), malu (ashamed), minta pisah (ask for divorce), saya biarkan (I let), saya berusaha (I try), untuk diam (to keep silent), dan melupakan (to forget). The use of the lexes and phrases express positive and negative attitudes. The phrases tidak tega (3/13)/ cannot hold on and malu (3/20a)/ ashamed expressed the negative attitude of the IMWs. The word berusaha (3/24a)/ try expressed positive attitude of the IMWs to do something, in this case diam (3/24b)/ to keep silent and melupakan (3/24b)/ to forget.

There was also a narration genre containing the complaints of the IMWs regarding to their husbands' behavior/attitude. The chart of the text is as follows:

TABEL 3. ATTITUDE IN NARRARTIVE TEXT

\begin{tabular}{|c|c|c|c|c|c|c|c|}
\hline \multirow[t]{4}{*}{ Teks } & \multicolumn{6}{|c|}{ Attitude } & \multirow{3}{*}{$\begin{array}{c}\text { Number } \\
\text { Of } \\
\text { Clause }\end{array}$} \\
\hline & \multicolumn{2}{|c|}{ Affect } & \multicolumn{2}{|c|}{ Judg. } & \multicolumn{2}{|c|}{ Apprc. } & \\
\hline & + & - & + & - & + & - & \\
\hline & 18 & 30 & 30 & 42 & 25 & 20 & 165 \\
\hline
\end{tabular}


In the narrative text, negative affects outnumber. Samples of the negative affects are as follows:

14) Aku jengkel (4/9a) (I was irritated)

15) Betapa kagetnya aku (4/25a) (How startled I was)

16) dan yang paling menyakitkan, (4/31d) (and the most painful was)

17) tiap hari aku selalu menangis (4/36b) ( everyday I always cry)

The samples (14-17) express the IMWs' complaints within the affect. Their complaints were also shown in judgment. For examples:

18) dan tetangga semua sudah tahu kalau suamiku selingkuh (4/27c) (and all neighbors know that my husband was cheating)

19) Selama ini ibuku dijadikan pembantunya (4/31e) (So far, my mother was treated as his servant).

Negative appreciations of the IMWs were also found. For examples:

20) Sejak mulai kerja dan ganti sepeda motor, suamiku jarang hubungi aku (4/22a) (Since he had job and had new motorcycle, my husband rarely contacted me).

21) Suamiku makin menjadi-jadi (4/29d) (My husband became out of control).

Source of attitude the narrative text were monoglos and heteroglos. Most heteroglos were projection (114) and concision (51).

\section{B. Discussion}

Final part of the research discussed the results which were linkage with the cultural theme in Indonesia. The discussion also answered the specified objectives.

In general, the complaints of the IMWs were written in Letter To Editor. In IQ and CQ Magazines, the rubric was Surat Pembaca, La Tahzan, or Curahan Hati. The text structure of Surat Pembaca and La Tahzan were prepared in question answer genre, with one text written in anecdote genre. The rubric of Curahan Hati was presented in narrative genre.

The application of a specific genre was adjusted to the ongoing social context. For example, the rubric of $L a$ Tahzan, which was intended for consultation, contained questions from its readers. The rubric of Curahan Hati contained narrations because the writers expressed their stories for other people to read.

The diction and lexis used by the IMWs could be categorized as fine/polite. Rude expressions were not found. They did not express their sadness in rude/impolite words. They try to make limitation in showing excessive attitudes. (Santosa et al, 2014)

Single voicing was used more in question answer text. This may because the writers were expressing their lives. In narrative genre, the heterogloss was used to expose or provide objective values upon the faced problems.

\section{V.CONCLUSION}

The complaints of the IMWs are visible in various genres. Problems related to their husbands produced negative attitudes.

They expressed their sadness by using words which were acceptable by Indonesians. Although problems appeared continually, the IMWs feel happy when their problems were solved. The dictions which showed thanks and happiness were found in the texts.

\section{References}

Halliday, M.A.K. (1985/1994). Introduction to functional grammar. London: Arnold.

Martin, J.R. (1992). English text: System and structure. Amsterdam: Banyamin.

Martin, J.R, \& David Rose. (2007). Working with discourse: meaning beyond the clause. New York: Continuum.

Martin, J.R, \& David Rose. (2008). Genre relation: mapping culture. London: Equinox Publishing Ltd.

Santosa, Riyadi. (2011). Logika wacana: analisis hubungan konjungtif dengan pendekatan linguistik sistemik fungsional. Surakarta: UNS Press.

Santosa, Riyadi. (2017). Metode penelitian kualitatif kebahasaan. Surakarta: UNS Press.

Santosa, Riyadi, Agus Dwi Priyanto, Ardiana Nuraeni. (2014). Genre and register of antagonist's language in media: an appraisal study of Indonesian newspapers. Jurnal Kata,16(1) (Online)

Spradely, James P. (1997). Metode etnografi. Yogyakarta: Tiara Wacana.

Sutopo, H.B. (2002). Metodologi penelitian kualitatif. Surakarta: UNS Press.

Tim Penyusun. (2009). Kamus besar bahasa Indonesia. Jakarta: Pusat Bahasa.

${ }^{1}$ http://sp.beritasatu.com/home/hong-kong-masih$\underline{\text { memesona-di-mata-tkw/18237 }}$ 